\title{
UNFAMILIAR INEQUALITIES
}

\section{Judy Walsh, Equality Studies Centre, University College Dublin}

\section{Introduction}

The conceptual underpinnings of Irish anti-discrimination measures and human rights law suffer from problems of breadth and depth and so are incapable of effecting radical changes to the social order. At best laws and policies framed around liberal principles seek to promote fairness in the competition for advantage, rather than tackling the social structures that continually generate unequal outcomes for minority groups. Moreover, these measures tend to shade out the affective aspects of people's lives, centring instead human activities and institutions associated with public sphere. Such a stance sits uncomfortably with the fact that many of the institutions of liberal societies are both dependent upon and have a direct impact on relationships of love and care. Being cared for is a fundamental prerequisite for human development; the emotional and material support people get from family and friends plays a vital role in sustaining their capacity to function as workers and citizens. It is therefore imperative that people are enabled to provide for, and benefit from care and love. At the same time, the organization of work and transportation has an obvious impact on the amount of time workers can spend with their families. And the way the state organizes residential facilities for disabled people, or denies accommodation to Travellers, has a huge impact on their personal relationships. Using a conception of equality termed "equality of condition", I examine the extent to which the Irish polity protects the intimate associations that sustain relations of love and care, focusing on the contribution of constitutional law. I argue that adoption of a relational approach to legal doctrine and method could promote a care-full conception of citizenship.

\section{Theoretical Approaches to Equality}

Looked at in a very general way, equality is a relationship, of some kind or other, between two or more people or groups of people, regarding some aspect of those people's lives. If equality were a simple idea, it would be obvious what this relationship is, who it is about and what aspect of their lives it concerns. Theorists have grappled with these questions for centuries and have arrived at various conceptions of equality, which colleagues at the Equality Studies Centre have loosely categorized as basic equality, liberal egalitarianism and equality of condition. ${ }^{1}$

A key assumption of the views we describe as liberal egalitarian is that there will always be major inequalities between people in their status, resources, work and power. The role of the idea of equality is to provide a fair basis for managing these inequalities, by strengthening the minimum to which everyone is entitled and by using equality of opportunity to regulate the competition for advantage. Variants of liberal egalitarianism supply the

1 J. Baker, K. Lynch, S. Cantillon and J. Walsh, Equality: From Theory to Action (2004). 
theoretical underpinnings of the human rights guarantees and antidiscrimination laws that proliferate in liberal democracies. Defined over several decades of activism and international negotiation, the human rights agenda is primarily concerned with the setting of minimum standards and promoting key principles of non-discrimination. While constitutional bills of rights generally, explicitly at least, address so-called "first generation" civil and political rights, ${ }^{2}$ within welfare states these protections tend to be supplemented by legislation and soft-law initiatives aimed at securing a floor of basic socio-economic entitlements and achieving equality of opportunity in certain settings. I consider below how this conceptual framework fails to capture adequately the inequalities operative in the sphere of the family. ${ }^{3}$

The radical idea of "equality of condition" we espouse sets out a much more ambitious aim: to eliminate major inequalities altogether, or at least massively to reduce the current scale of inequality. ${ }^{4}$ The key to this much more ambitious agenda is to recognize that inequality is rooted in changing and changeable social structures, and particularly in structures of domination and oppression. These structures create, and continually reproduce, the inequalities that liberal egalitarians see as inevitable. But since social structures have changed in the past, it is at least conceivable that they could be deliberately changed in the future. Exactly how to name and analyse these structures and their interaction is a matter of continuing debate, but one way or another they clearly include capitalism (a predominantly market-based economy in which the means of production are privately owned and controlled), patriarchy (systems of gender relationships that privilege men over women), racism (social systems that divide people into "races" and privilege some "races" over others) and other systems of oppression such as ageism, disablism and heterosexism.

This emphasis on social structures in explaining inequality affects the way equality of condition should be understood and embedded within the legal system. For example, in contrast to the tendency of liberal egalitarians to focus on the rights and advantages of individuals, equality of condition also pays attention to the rights and advantages of groups. Whereas liberal egalitarians tend to concentrate on how things are distributed, equality of condition pays more attention to how people are related, particularly through power relations. Equality of condition also emphasizes the influence of contextual factors on people's ostensibly free choices and actions. I argue

2 See generally C. Fabre, Social Rights under the Constitution: Government and the Decent Life (2000).

3 Indeed, Irish constitutional law in this domain combines formal equality principles with adherence to a set of communitarian, theocratic values.

4 The idea of equality of condition draws on a wide range of sources, including $\mathrm{J}$. Baker, Arguing for Equality (1987); J. H. Carens, Equality, Moral Incentives, and the Market (1981); G. A. Cohen, If You're an Egalitarian, How Come You're So Rich? (2000); N. Fraser, Justice Interruptus (1997); K. Nielsen, Equality and Liberty (1985); R. Norman, Free and Equal (1987); S. M. Okin, Justice, Gender, and the Family (1989); A. Phillips, Which Equalities Matter? (1999); J. H. Schaar, "Equality of Opportunity, and Beyond", in J. R. Pennock and J. Chapman, eds., Nomos IX: Equality (1967), at pp.228-49; and I. M. Young, Justice and the Politics of Difference (1990). There are of course many differences among these authors; our aim is to draw together their most important insights. 
below that a relational concept of rights holds promise for proponents of radical egalitarianism.

In exploring the differences between liberal and radical models we distinguish five key dimensions of equality: (1) respect and recognition, (2) power, (3) resources, (4) working and learning and (5) love, care and solidarity. ${ }^{5}$ These dimensions of equality represent some of the key factors that affect nearly everyone's well being or quality of life. Equality of condition calls not just for the toleration of differences, but for a "critical inter-culturalism" that encourages the members of different social groups to engage in a mutually supportive but critical dialogue from which everyone can learn, leading to equality of respect and recognition. In the dimension of power, it means the roughly equal enabling of each person to influence the decisions that affect their lives, both within the formal political system and throughout society. Aimed at ensuring that people have a broadly equivalent range of resource-dependent options, equality of condition not only means moving beyond poverty reduction goals to achieve greater equality of wealth and income, but also embraces non-financial goods, such as a right to accessible public services. It demands that the burdens and benefits of work should be much more equally shared and that the conditions under which people work should be much more equal in character. And it calls for ensuring that everyone has access to forms of learning that contribute to their self-development in the broadest sense.

Equality of condition also aims for social conditions under which people would have ample prospects for loving, caring and solidary relationships. Human beings typically have both a need and a capacity for intimacy with, and attachment, to others. All of us have urgent needs for care at various stages in our lives, as a consequence of infancy, illness, impairment or other vulnerabilities, while solidary bonds of friendship or kinship are frequently what bring meaning, warmth and joy to life. Being deprived of the capacity to develop such supportive affective relations, or of the experience of engaging in them when one has the capacity, is therefore a serious human deprivation for most people. Relations of love, care and solidarity are both a vital component of what enables people to lead successful lives and an expression of our fundamental interdependence.

We elaborate on this conceptual framework by discussing four central social systems as contexts of egalitarian change. ${ }^{6}$ In line with the sociological tradition of Marx, Weber and Parsons, we distinguish the economic system from the cultural system and the political system. However, influenced by feminist theory, we also address the importance of the affective system - the system concerned with providing and sustaining relationships of love, care and solidarity. ${ }^{7}$ Analysing a society in terms of social systems is a way of

5 See generally Baker et al, above n.1, chap.2.

6 See Baker et al, above n.1, chap.4.

7 The affective system was traditionally neglected across various fields of academic inquiry and only began to be addressed as feminist scholarship highlighted the importance of care and love work within the lives of women particularly. Some key contributions include, D. E. Bubeck, Care, Gender, and Justice (1995); B. Hobson ed., Gender and Citizenship in Transition (2000); M. C. Nussbaum, "Emotions and Women's Capabilities", in M. Nussbaum and J. Glover, eds., Women, Culture and 
trying to get a sense of the central sets of relationships that structure people's lives and in particular account for the inequalities between social groups. The political, economic, cultural and affective systems are not independent, but on the contrary are deeply intertwined, both conceptually and empirically: Each system is partly constituted by the others and structural inequalities related to class, gender, disability, ethnicity, sexuality are persistent precisely because they are reinforced in all of the key social systems.

Identifying the affective system as a context of equality is meant to emphasise that the set of social relations that go into providing love, care and solidarity is itself a set of relations that involve inequalities, not just of love, care and solidarity, but also, for example, of respect and work burdens. Inequality in the affective domain takes two primary forms: when people have unequal access to meaningful loving and caring relationships, and when there is inequality in the distribution of the emotional and other work that produces and sustains such relationships. The types of people who are likely to be deprived of love and care (for example, children who are left without a primary carer and certain migrant populations) are generally very different from those who experience affective inequality due to undertaking a disproportionately high level of care work (women compared with men). Families are the key institutions in contemporary societies for providing love and care, ${ }^{8}$ although these relationships are also sustained by networks of friendship and by public and commercial institutions. As Sevenhuijsen observes: "care takes place in all kinds of contexts, from child-rearing practices to intimate relations, to the social services, education and political deliberation." "9

It is an important issue of equality, and therefore of justice, to ask who has access to, and who is denied, relations of love, care and solidarity, whether these relations are reciprocal or asymmetrical, and whether the ways societies operate help to satisfy or frustrate these human needs. Equality of condition envisages a society in which people are confident of having, if not equal, then at least ample prospects for loving, caring and solidary relationships. To achieve this goal, it is necessary to change structures and institutions that systematically impede people's opportunities to develop such relationships, including the organization of paid work, processes of gender stereotyping and the gendered division of labour, ${ }^{10}$ attitudes and institutional arrangements concerning disability, and of course the burdens of poverty and deprivation.

Development: A Study of Human Capabilities (1995), pp.360-395; S. Sevenhuijsen,Citizenship and the Ethics of Care: Feminist Considerations on Justice, Morality and Politics (1998).

8 Including the families of choice that are especially important in the lives of those whose families of origin have been a site of oppression or constraint, see M. Friedman, "Feminism and Modern Friendship: Dislocating the Community" in C. Sunstein ed., Feminism and Political Theory (1990); J. Weeks et al, "Everyday Experiments: Narratives of Non-Heterosexual Relationships" in E.B. Silva and C. Smart eds., The New Family? (1999), at pp.83-99.

9 Sevenhuijsen, above n.7, at p.22.

10 As Fraser, above n.4, at p.61, argues: "The key to achieving gender equity in a postindustrial welfare state. . . is to make women's current life patterns the norm for everyone." 
The legal system is an important site of critical inquiry and activation for progressive change since it is tasked with regulating all other social institutions and is located at the intersection of state and civil society. A central purpose of this article is to illustrate how the legal system, as a core element of the political system, interacts with the affective context. While law is the product of social relations, it simultaneously shapes various social practices including those pertaining to intimate associations on both a material and ideological plane. ${ }^{11}$ As Brophy and Smart put it:

'Law sets the parameters to what is considered 'normal', for example marriage, sexual relations, the way we care for our children. . . . We cannot 'opt out' of these legal parameters by adopting unconventional lifestyles or by avoiding heterosexuality. The law still has something to say about our domestic lives and intimate relations, and we cannot assert its irrelevance by ignoring it."12

Constitutional rights and the associated mechanism of judicial review lie at the centre of the "social contract" that mediates sets of relationships among individuals, groups and institutions within liberal democracies. Critical literature forcefully illustrates, however, that courts are not neutral mediators of various interests; legal doctrine and methodology tends instead to reinforce the position of dominant groups. ${ }^{13}$ In a subsequent section I explore how the Irish courts have interpreted and enforced those "contractual terms" that directly concern relations of love and care. Using the position of children, sexual minorities and carers as exemplars, I demonstrate that the demarcation of private and public spheres envisaged by liberal political

11 See further A. Hunt, Explorations in Law and Society: Toward a Constitutive Theory of Law (1993), p.3. For examples of constitutive approaches to the relationship between law and society see J. Brigham, "The Constitution of Interests: Institutionalism, CLS and New Approaches to Sociolegal Studies" (1998) 10 Yale J. L. \& Human. 421; P. Ewick and S. Silbey, The Common Place of Law: Stories From Everyday Life (1998); R. W. Gordon "Critical Legal Histories" (1984) 36 Stan. L. Rev 57; A. Hunt, Explorations in Law and Society: Toward a Constitutive Theory of Law (1993); M. McCann, Rights at Work: Pay Equity Reform and the Politics of Legal Mobilization (1994); J. Nice, "Equal Protection's Antinomies and the Promise of a Co-Constitutive Approach" (2000) 85 Cornell L. Rev 1392.

12 J. Brophy and C. Smart, Women-in-Law: Explorations of Law, Family and Sexuality (1985), p.1.

13 See, e.g. K. T. Bartlett and R. Kennedy, Feminist Legal Theory: Readings in Law and Gender (1991); P. Bourdieu, "The Force of Law: Toward a Sociology of the Juridical Field", tr. R. Terdiman (1987) 38 Hastings L. J. 805; A. Bottomley and J. Conaghan eds., Feminist Theory and Legal Strategy (1993); R. Delgado and J. Stefancic eds., Critical Race Theory: An Introduction (2001); S. Edwards, Sex and Gender in the Legal Process (1996); D. Kairys ed., The Politics of the Law: A Progressive Critique, $3^{\text {rd }}$ ed. (1998); N. Lacey, Unspeakable Subjects: Feminist Essays in Legal and Social Theory (1998); C. A. MacKinnon, Feminism Unmodified: Discourses on Life and Law (1987); C. Smart, Feminism and the Power of the Law (1989); C. Stychin and D. Herman eds., Sexuality in the Legal Arena (2000); K. D. Weisberg (ed.) Feminist Legal Theory: Foundations (1993); P. J. Williams, The Alchemy of Race and Rights (1991). 
theory is shot through with adherence to a set of theocratic values, so that the affective domain is "private" for some purposes and public for others. In each instance the courts' stance entrenches the affective inequalities experienced by minority groups and reinforces a gender order that perpetuates inequalities both as between women and men and among men. Before examining State regulation of the affective context I outline the contours of a relational conception of rights, suggesting that such an approach has the capacity to advance equality of condition within the legal field.

\section{Rights as Relational}

As Wilson notes, human rights have become "one of the most globalized political values of our times". ${ }^{14}$ The proliferation of rights has proceeded along three dimensions: a widespread increase in the establishment of new legal rights; the assertion of ever more moral rights that are as yet not acknowledged in law; ${ }^{15}$ and the increased use of rights-talk in political discourse. ${ }^{16}$ These developments have coincided with scepticism amongst political philosophers as to the feasibility and indeed utility of anchoring human rights in universal moral foundations. ${ }^{17}$ Left legal scholarship has also subjected rights theory and practice within liberal democracies to trenchant critique, the main strands of which are discussed below. ${ }^{18}$ Nonetheless a widespread consensus exists to the effect that "rights matter". ${ }^{19}$ Feminist and critical race scholars in particular have advanced both pragmatic and theoretical arguments to the effect that rights can be re-configured to advance substantive equality goals. For Williams and Crenshaw claims articulated in other terms are unlikely to be heard. ${ }^{20}$ Further, rights talk has a deep cultural resonance for oppressed groups, a point borne out by the Irish disability

14 R. Wilson, "Human Rights, Culture and Context: An Introduction" in R. Wilson ed., Human Rights, Culture and Context: Anthropological Perspectives (1996), p.1.

15 A current example being the Irish disability rights movement's attempts to ensure that the provision of various services is rendered rights-based in a legal sense. Indeed, this ongoing campaign forms part of a wider debate about the justiciability of social and economic rights generally. See for example, Irish Human Rights Commission, Observations on the Disability Bill 2004 (2004).

16 See C. Wellman, The Proliferation of Rights: Moral Progress or Empty Rhetoric? (1999).

17 Attempts to ground human rights in timeless and fixed human attributes such as "rationality" have been subject to robust critique by Richard Rorty for example cf. "Human Rights, Rationality, and Sentimentality" in S. Shute and S. Hurley eds., On Human Rights: The Oxford Amnesty Lectures 1993 (1993), pp. 111-134; For an overview of these debates see S. Mendus, "Human Rights in Political Theory" in D. Beetham ed., Politics and Human Rights (1995), pp.10-24.

18 Critiques of rights are not of course confined to those who identify with left politics, but I focus on these criticisms here.

19 See further J. Waldron ed., Theories of Rights (1984); A. Sen, "Elements of a Theory of Human Rights" (2004) 32 Phil. \& Pub. Aff. 315.

20 P. J. Williams, "Alchemical Notes: Reconstructing Ideals From Deconstructed Rights" (1987) 22 Harv C. R.-C.L. L. Rev 401; K. Crenshaw, "Race, Reform and Retrenchment: Transformation and Legitimation in Antidiscrimination Law" (1988) 101 Harv L. Rev 1331. 
movement's continued assertion of rights before a recalcitrant government. ${ }^{21}$ The central idea is that rights are not inherently limiting, rather the problem is that they operate with a "limited institutional, imaginative universe". ${ }^{22}$

A relational approach presents interesting opportunities for scholars and practitioners who believe that rights remain an important framework within which egalitarian political ideals can be progressed. ${ }^{23}$ Under this approach legal rights are not singular objects possessed by individuals but social relationships that are reduced to a written text in order to be captured by law. ${ }^{24}$ As Minow argues, because legal rights "arise in the context of relationships among people who are themselves interdependent and mutually defining..." they are best configured as "simply the articulation of legal consequences for particular patterns of human and institutional relationships." ${ }^{25}$ Nedelsky also makes both a normative and empirical claim in asserting that all rights are relational: "In brief, what rights in fact do and have always done is construct relationships - of power, of responsibility, of trust, of obligation." 26 While the surface inquiry conducted by a court may present an understanding of rights as shielding the individual from the tyranny of the majority, a question of rights "trumping" the common good, ${ }^{27}$ the actual structure of decisions reveals that they are vehicles for achieving various collective goals. In other words, our individual rights derive their meaning from and are reliant on the social position of others. Thus inevitably legal reasoning is already relational but tends to prioritise proprietary

21 See for example Disability Legislation Consultation Group, Equal Citizens: Proposals for Core Elements of Disability Legislation (2003).

22 D. L. Rhode, "Feminist Critical Theories", in Bartlett and Kennedy eds., above n.13, at p.343. See also W. Brown, States of Injury: Power and Freedom in Late Modernity (1995), chap.5.

23 This project is prompted to an extent by scholarship across a range of disciplines that seeks to reconcile the ethic of care with the ethic of justice. A significant strand of feminist work on the ethic of care was prompted by Carol Gilligan's research on moral psychology $c f$. In a Different Voice (1982). While Nel Noddings in Caring: A Feminine Approach to Ethics and Moral Education (1994), argues for the primacy of an ethic of care, Bubeck, above n.7, maintains that an ethic of care needs to be complemented by considerations of justice and puts forward two principles of justice in care. Kittay, above n.7 at p.103, suggests that "the good both to be cared for in a responsive dependency relation if and when one is unable to care for oneself, and to meet the dependency needs of others without incurring undue sacrifices oneself is a primary social good in the Rawlsian sense" which requires a separate principle of justice and calls for a connection-based conception of equality.

24 Young, above n.4 at p.25; Jennifer Nedelsky, "The Practical Possibilities of Feminist Theory" (1993) 87 Nw. U. L. Rev 1286 at p.1289. See also R. Pildes, "Why Rights are not Trumps: Social Meanings, Expressive Harms and Constitutionalism" (1998) 27 JLS 725.

25 M. Minow, "Interpreting Rights: An Essay for Robert Cover" (1987) 96 Yale L.J. 1860 at 1884.

26 J. Nedelsky, "Reconceiving Rights as Relationship" (1993) 1 Rev Const. Stud. 1 , at p.13.

27 The characterisation of rights as "trumps" designed to protect the individual from the collective will advanced by legislatures is traceable to Ronald Dworkin's Taking Rights Seriously (1977). 
relations rather than interpersonal affective ties. ${ }^{28}$ The radical egalitarian task therefore, is twofold: to expose the unarticulated premises and invisible mechanisms through which relational principles enter the law and to ensure that those principles foster relationships, which will advance rather than impede substantive equality. ${ }^{29}$ Later on I make some tentative suggestions as to how this project could be realised. I now turn to assess governmental responses to the affective context, tracing the main impetus of policies and legislative measures, before going on to consider relevant constitutional jurisprudence.

\section{State Regulation of the Affective Context}

Demographic change, primarily an ageing population and increased female participation in the labour market, has propelled issues of care on to the policy agendas of welfare states including that of Ireland. Throughout Europe the crisis over the work involved in caring has become a political issue although it is not named in these terms. It is defined as a problem of "work-life balance" that demands "family friendly" policies from employers and governments. ${ }^{30}$ The silencing of the politics of care and love work stems in considerable part from the conception of the citizen that has informed contemporary politics; citizens have been defined as warriors, as workers but never carers. ${ }^{31}$ Citizenship has been equated with one's public rather than personal obligations and commitments. At EU level, for example, most legal protections are for paid workers, those who contribute to the formal economy. ${ }^{32}$ Yet no economy or society can function effectively without care work. It is not surprising, therefore, that the affective has become a mobilizing narrative for social movements in part because of the growing tensions between care work and capitalism, and especially between such work and paid employment; a conflict that is exacerbated in Ireland by inadequate public care infrastructure. ${ }^{33}$ Given recent developments in other countries, debates about recognition of gay and lesbian partnerships have inevitably filtered into the Irish political arena. ${ }^{34}$ Recent initiatives include

28 See Nedelsky, above n.26; D. Abraham, "Liberty without Equality: The PropertyRights Connection in a 'Negative Citizenship' Regime” (1996) 21 Law and Social Inquiry 1.

29 I will argue below that the Canadian and South African Supreme Courts' jurisprudence on equality embraces a relational concept of rights on occasion.

30 European Commission, Confronting Demographic Change: A New Solidarity between the Generations (2005); European Foundation for the Improvement of Living and Working Conditions, Combining Family and Full-Time Work (2005).

31 S. Baer, "Citizenship in Europe and the Construction of Gender by Law" in K Knop ed., Gender and Human Rights (2004), pp.83-112; R. Lister, "Dilemmas in Engendering Citizenship" in Hobson ed., above n.7, pp.33-83; S. Sevenhuijsen, above n.7.

32 See Baker et al, above n. 1, chap.7.

33 See Equality Authority, Implementing Equality for Carers (2005); J. MurphyLawless \& P. Kennedy, The Maternity Care Needs of Refugee and Asylum Seeking Women (2002).

34 The Equality Authority has played a central role in this regard see Implementing Equality for Lesbians, Gays and Bisexuals (2002); J. Mee \& K. Ronayne, Partnership Rights of Same Sex Couples (2000). See also National Economic and Social Forum, Equality Policies for Lesbian, Gay and Bisexual People: 
the introduction of a Private Members Bill on civil unions before the national Parliament and ongoing litigation challenging the treatment of a lesbian couple under the taxation code. ${ }^{35}$ The imminent establishment of a governmental working group on partnership rights provides the clearest indication to date that legal change is on the horizon. ${ }^{36}$ Yet a cautionary note needs to be sounded with respect to marriage and other types of relationship registration. ${ }^{37}$ As discussed below, such contracts tend to reinforce the privatisation of responsibility for care and in particular can disadvantage partners who do not engage in paid employment. ${ }^{38}$

"Under conditions of declining public support, broader definitions of family may simply mean more people are conscripted into care rather than better care giving or better relationships. Unless there are formal supports for unpaid care giving, both the caregivers and their relationships are increasingly likely to fall apart." 39

Anchored in variants of liberal theory, state responses to inequalities arising in the affective context overlook the extent to which care is nested in a set of power relations and ensure the resilience of a public/private divide that locates primary responsibility for dependence within the family. ${ }^{40}$ Rather than tackling directly the generative causes of inequality, the emphasis is on strengthening the social minimum while using equality of opportunity to achieve fairness in the competition for a more favourable place in unequal structures. Thus despite considerable institutional and legislative activity aimed at establishing an infrastructure for equality, putting in place rightsbased legislation and developing specific policy initiatives, the gains, in equality terms, have been largely formal rather than substantive. ${ }^{41}$

Implementation Issues (2003); Law Reform Commission, Consultation Paper on the Rights and Duties of Cohabitees (2004).

35 See Irish Council for Civil Liberties, Equality for all Families (forthcoming, 2006).

36 Irish Times, December 21st 2005.

37 On the tension between the politics of "recognition" and "redistribution" generally see Fraser, above n.4, pp.11-39.

38 See K. Lahey, The Impact of Relationship Recognition on Lesbian Women in Canada (2001).

39 P. Armstrong and O. Kits, One Hundred Years of Caregiving (2001), at 33.

40 I argue below that anti-discrimination laws are a quintessential example of this model of the relation between "public" and "private". Although they "intervene" in the market, they do not question the ownership of the means of production and they confine themselves to paid work, excluding the unpaid labour undertaken, primarily by women, in the home.

41 The past decade has witnessed, for example, the establishment of the Equality Authority, the National Consultative Committee on Racism and Interculturalism, the National Disability Authority, the Office for Social Inclusion, the Children's Ombudsman and the Human Rights Commission. Benign legislative enactments include the Employment Equality Acts 1998-2004, the Equal Status Acts 20002004, the Carer's Leave Act 2001, the European Convention on Human Rights Act 2003 and the National Minimum Wage Act 2000. Significant policy measures introduced over the same period include the National Children's Strategy (2000) and the National Action Plan Against Poverty and Social Inclusion (2003-05). 
Liberalism, as currently realised through state law and policy, assumes that the patterns of distribution and power relations at play in given contexts arise naturally and independently of State action; as a result, "intervention" in arenas such as the economy and family should occur only within prescribed limits. ${ }^{42}$ Social welfare benefits and entitlements are drawn with reference to the "non-productive" status of those who give and receive care, and often institutionalised in a manner that allows bureaucracies to police the claimants' behaviour. ${ }^{43}$ In combination with taxation measures, the net policy goal is to discourage "dependence" on the state and induce individuals to rely upon the market for an adequate income. ${ }^{44}$ A report commissioned by the Equality Authority highlights the residual role played by the State in the provision of care while underlining the tension between market-driven policies and the provision of key social services: "Put crudely, current employment policy is oriented towards increasing participation rates for all groups, including carers, and current health policy is predicated on continued availability of informal carers to provide the vast bulk of care and support in the community." 45

Empirical evidence underscores this stark relationship between the affective and the economic. The latest data reveals that in 2003 almost one-fifth of the population were at risk of poverty. ${ }^{46}$ Indeed, despite a fifteen-year period of unprecedented economic growth Ireland has one of the highest levels of child poverty in the OECD. ${ }^{47}$ While overall economic prosperity has contributed to an improved position on the 2005 UN Human Development Index, the same report highlights relatively low levels of social expenditure and an increasing gap between rich and poor. ${ }^{48}$ Under-funding of public services when allied to State policies that promote paid employment as a route out of poverty, widens inequality of resources as between those who can take up such employment and those whose cannot by reason of age, disability or their occupation as carers. Studies issued by domestic and transnational bodies have consistently found that one's family status is a key determinant of economic security. ${ }^{49}$ Spouses who work full-time in the home are treated as dependent under the social welfare system (as are unmarried opposite-sex

42 For a critique of the liberal defence of family privacy see Okin, above n.4.

43 M. Diller, "The Revolution in Welfare Administration: Rules, Discretion, and Entrepreneurial Government" (2000) 75 N. Y. U. L. Rev 1121; J. Habermas, The Theory of Communicative Action. Vol. 2, Lifeworld and System: A Critique of Functionalist Reason (1987), at pp.361-73; J. Handler, "Constructing the Political Spectacle: The Interpretation of Entitlements, Legalization, and Obligations in Social Welfare History" (1991) 56 Brooklyn L. Rev 899; L. Williams, "Welfare Law and Legal Entitlements: The Social Roots of Poverty", in Kairys, above n. 13, at pp.569-590; V Zeziler, The Social Meaning of Money (1994).

44 N. Fraser and L. Gordon, "A Genealogy of 'Dependency" in Fraser, above n.4 at pp.121-149.

45 K. Cullen, S. Delaney and P. Duff, Caring Working and Public Policy (2004), at p. 19.

46 Central Statistics Office, EU Survey on Income and Living Conditions (2005).

47 UNICEF, Child Poverty in Rich Countries (2005).

48 United Nations Development Programme, Human Development Report 2005 (2005). See also V. Timonen, Irish Social Expenditure in a Comparative International Context: Epilogue (2005).

49 See generally the Combat Poverty Agency's website :http://www.cpa.ie/; See also Central Statistics Office, above n.46. 
cohabitees in some contexts), an ascription has particular repercussions for social insurance and access to pensions, exacerbating the established disproportionate poverty risk faced by older women. ${ }^{50}$ Of the 150,000 fulltime carers that save the state an estimated $€ 1.5$ billion per annum, just one in six is entitled to the means-tested Carer's Allowance. ${ }^{51}$

A "moral economy" 52 is operative that not only conceals the manner in which carers provide a massive subsidy to the state and society generally, but also instils a discourse of entitlement patterned according to one's group membership. ${ }^{53}$ The interaction between affective and other inequalities is particularly visible in the lives of economic migrants and refugees, whose love and care needs are severely affected by failure to institute coherent family re-unification policies and also by the material conditions in which they are forced to live. ${ }^{54}$ According to Loyal, a period of net inward migration has witnessed the re-emergence of a Victorian distinction between a deserving and undeserving poor in terms of a "putative difference between 'genuine' refugees (deserving), of whom there are too few, and 'bogus' refugees (undeserving), of whom there are too many." 55 The social position of Ireland's largest ethnic minority continues to be characterised by intolerable levels of inequality across all five dimensions. ${ }^{56}$ Local authorities have been slow to create and improve accommodation for Travellers and unauthorized halting has been criminalized. ${ }^{57}$ Enactment of legislation that

50 See, e.g. National Women's Council of Ireland. Women and Poverty: Factsheet No. 2 (2003) which reports that: "More than 70 percent of women do not have occupational pensions (due to their leaving the workforce to undertake caring work); this has significant financial implications for older women". See also M. Murphy, A Woman's Model for Social Welfare Reform (2003).

51 Carers Association of Ireland, Pre-budget Submission to the Government of Ireland: Budget 2006 (2005).

52 A. Sayer, "Equality and Moral Economy", Paper presented at the Equality Studies Centre 10th Anniversary Conference, University College Dublin, 15 December 2000.

53 Despite the established connection between poverty and membership of the social groups alluded to in Irish anti-discrimination legislation "there is no evidence that these inequalities are specifically addressed within the poverty proofing process" according to the National Economic and Social Council, Review of the Poverty Proofing Process (2001), p.52. See further Combat Poverty Agency and Equality Authority, Poverty and Inequality: Applying an Equality Dimension to Poverty Proofing (2003).

54 B. Fanning et al, Beyond the Pale: Asylum-Seeking Children and Social Exclusion in Ireland (2001); Free Legal Advice Centre, Direct Discrimination?: An Analysis of the Scheme of Direct Provision in Ireland (2003); Irish Human Rights Commission and NCCRI, Safeguarding the Rights of Migrant Workers and their Families (2004).

55 S. Loyal, "Welcome to the Celtic Tiger: Racism, Immigration and the State" in S. Coulter and S. Coleman eds., The End of Irish History?: Critical Reflections on the Celtic Tiger (2003), at p.84.

56 Pavee Point, Assimilation Policies and Outcomes: Travellers' Experience (2005); Second Progress Report of the Committee to Monitor and Co-Ordinate the Implementation of the Recommendations of the Task Force on the Travelling Community (2005).

57 Housing (Miscellaneous Provisions) Act 2002, s.24. See generally, Council of Europe, Advisory Committee on the Framework Convention for the Protection of National Minorities: Opinion on Ireland, (2003). 
equates a person's home with an "object" which may be removed and ultimately disposed of by policing authorities seriously exacerbates the affective inequalities experienced by this group. Disabled people also experience high levels of poverty ${ }^{58}$ and under the Disability Act 2005 continue to be construed as needy objects of policy as opposed to subjects of justiciable rights. ${ }^{59}$

The gender politics of care is underlined in a substantial body of feminist literature, due no doubt to the fact that women undertake a disproportionately high level of care and love work throughout the world. ${ }^{60}$ Ireland is no exception; the proportion of women heading lone parent families was $91.7 \%$ in 2005 and less than $1 \%$ of persons whose principal activity was looking after home/family were men. ${ }^{61}$ With respect to the provision of regular unpaid care to wider groups of people the gender breakdown is more even; $61.4 \%$ were female. ${ }^{62}$

Family and employment law modify the usual rules of property, contract and tort in order to take account of interdependence. Although statutes that provide for the re-distribution of property as between married family members afford some recognition to the value of care work at a horizontal level, ${ }^{63}$ they also ensure that the costs of social reproduction are still largely privatised. ${ }^{64}$ Legislation prohibiting discrimination on the grounds of gender and marital status within paid employment has been in place for the past three decades. ${ }^{65}$ More recently the bases for claims and their sphere of application has expanded considerably yet the family sphere is effectively sealed off from the reach of equality law.

The Employment Equality Acts 1998-2004 and the Equal Status Acts 20002004 are the two main vehicles through which equality of opportunity is advanced within the Irish State. While the legislation has secured positive change for a considerable number of individuals, we need to be cognisant of its inherent limitations. Liberal equality of opportunity means that people should in some sense have an equal chance to compete for social advantages. This principle has two major interpretations. The first, "formal" equal opportunity classically gives rise to injunctions that all persons should be treated equally, thereby endorsing a "sameness" approach to equality. ${ }^{66} \mathrm{~A}$

58 B. Gannon and B. Nolan, Disability and Social Inclusion in Ireland (2005).

59 See J. De Wispelaere. \& J. Walsh (2005) "Rights or Policy?: Arguing for a Rightsbased Approach to Disability Services", Unpublished Paper Presented to the Society for Applied European Thought Conference, Inclusions and Exclusions in the New Europe, Tatranská Lomnica: Slovakia, 3-8 July 2005.

60 M. Daly ed., Care Work: The Quest for Security (2001).

${ }^{61}$ Central Statistics Office, Women and Men in Ireland 2005 (2005).

62 ibid.

63 N. Yeates, "Gender, Familism and Housing: Matrimonial Property Rights in Ireland" (1999) 22 Women's Studies International Forum 607.

64 See for example S. Boyd, "Family, Law and Sexuality: Feminist Engagements" (1999) 8 Social \& Legal Studies 369.

65 See generally M. Bolger and C. Kimber, Sex Discrimination Law (2001).

66 This approach is embodied in the prohibitions of direct discrimination found in the EEA and ESA. A claim can be taken on any one, or several of, nine specified grounds viz. age, disability, gender, family status, membership of the Travelling community, marital status, race, religion and sexual orientation. 
stronger form of equal opportunity insists that people should not be advantaged or hampered by their social background and that their prospects in life should depend entirely on their own effort and abilities. In turn such an approach can give rise to laws and policies which mandate that in certain contexts people should be treated differently so that they arrive at an equal starting point in the competition for advantage.

Provisions aimed at accommodating "difference" currently take a variety of forms. Those pertaining to disabled people require adjustments in workplace practices and environments to enable them to participate in the labour market. ${ }^{67}$ Similar measures operate to facilitate workers with family responsibilities but these are generally confined to statutory leave entitlements. ${ }^{68}$ For carers the radical promise of indirect discrimination is undercut by the fact that its primary purpose is to diagnose discrimination rather than effecting equality of outcome. ${ }^{69}$ The cumulative effect is that while an employee may take time off work for maternity, parental or caretaking purposes, employers are not required to restructure workplaces so that love and care labour can be undertaken without a resultant loss in status or opportunity in market terms. So-called "family friendly" work arrangements are instigated at the discretion of employers ${ }^{70}$ and are therefore contingent on the bargaining power of employees and on wider labour market considerations. ${ }^{71}$ Furthermore, the care activities of some groups are fully externalized through the operation of various exemptions. For example, an employer may refuse to confer rights on an employee's partner because they are not married, irrespective of the fact that such a policy amounts to indirect discrimination on the grounds of sexual orientation. ${ }^{72}$ Exclusion of employees with same-sex partners from family based benefits not only constitutes a material deprivation but expresses unequal recognition and jeopardizes equality of love and care.

While, labour law makes some modest concessions to those who are "different", it ultimately reinforces a vision of the benchmark citizen as one who does not demand "special" treatment; he is not disabled, does not become pregnant or have domestic responsibilities. ${ }^{73}$ At the same time, precisely because it has not dealt with the structures generating inequality,

67 EC Directive 2000/78, Art. 5; Employment Equality Acts 1998-2004, s.35. For a critical appraisal of reasonable accommodation and the supposed distinction between direct and indirect discrimination see, S. Day \& G. Brodsky "The Duty to Accommodate: Who Will Benefit?" (1996) 75 Can. Bar Rev 433.

68 Adoptive Leave Act 1995; Carer's Leave Act 2001; Maternity Protection Acts 1994-2004; Parental Leave Act 1998.

69 S. Fredman, "Equality: A New Generation?" (2001) 30 ILJ 145.

70 See Walsh v Tesco (ODEI-DEC-E2001-042); Tesco v a Worker (LC DEE014).

71 See generally, H. Fisher, Investing in People: Family Friendly Work Arrangements in Small and Medium-Sized Enterprises (2000); P. Humphries et al, Balancing Work and Family Life: The Role of Flexible Working Arrangements (2000).

72 See definition of 'family' and exemptions set out in ss.2 and 34 EEA respectively. M. Bell, "Sexual orientation in employment: An evolving role for the European Union", in Wintemute \& Andenaes, Legal Recognition of Same sex Partnerships A Study of National, European and International law (2001).

73 For a fuller account of the limits of Irish anti-discrimination law see Baker et al, above n.1, chap.7. 
anti-discrimination legislation entails continuous remedial activity. The result, as Fraser notes, is to "mark the most disadvantaged class as inherently deficient and insatiable, as always needing more and more". ${ }^{74}$ Marketcentred laws also permit new pockets of inequality to emerge. Labour undertaken in the home may result in a double shift for women in employment $^{75}$ or be delegated to a new primarily female underclass, whose own caring tasks are not part of the equal opportunities equation. ${ }^{76} \mathrm{An}$ "opportunity" in this context is the right to compete, not the right to choose among alternatives of similar worth.

In this section I have argued that as markets encroach on the redistributive function of the welfare state the claims of subordinate groups to various forms of social assistance meet considerable opposition. Resistance to narratives of love, care and solidarity comes not only from those who regard such issues as private, un-nameable, non-political matters, but also from those who fear that such narratives would distract from a necessary materialist analysis of economic and political relations. ${ }^{77}$ What is all too often ignored is the materiality of love and care: the affective and the economic are deeply implicated with each other.

The following section considers the extent to which constitutional law has fostered or impeded the attainment of affective equality in relation to three social groups, children, carers and sexual minorities.

\section{Constitutional Jurisprudence}

An obvious starting point for consideration of the affective domain is jurisprudence concerning Articles 41-42, which are headed "The Family". Courts are working with raw material that is "heavily influenced by Roman Catholic teaching and Papal encyclicals", ${ }^{78}$ endorses a gendered division of labour, imbues the marital family with inalienable and imprescriptible rights and seeks to protect it from "attack". ${ }^{79}$ Despite widespread judicial consensus to the effect that the Constitution is a living document that ought to evolve in line with changes in Irish society, ${ }^{80}$ successive judgments reiterate a narrow

74 Above n.4, p.25.

75 See A. Hochschild, The Second Shift: Working Parents and the Revolution at Home (1989). For an empirical picture of this gendered division of labour see European Foundation for the Improvement of Living and Working Conditions, Gender, Jobs and Working Conditions in the European Union (2002).

76 See generally J. Tronto, "The Nanny Question in Feminism" (2002) 7 Hypatia 34.

77 M. H. Marchand and A. S. Runyan, "Feminist Sightings of Global Restructuring: Conceptualizations and Reconceptualizations" in Marchand and Runyan eds., Gender and Global Restructuring: Sightings, Sites and Resistances (2000), pp.125; J. White and J. Tronto, "Political Practices of Care: Needs and Rights" (2004) 17 Ratio Juris 425.

78 Government of Ireland, Report of the Constitution Review Group (1996), p.319.

79 See discussion by A. Connelly, "Women and the Constitution of Ireland" in Galligan, Ward and Wilford eds., Contesting Politics: Women in Ireland, North and South, (1999), pp.18-37; and L. Flynn, "To be an Irish Man-Constructions of Masculinity in the Constitution", in T. Murphy and P. Twomey eds., Ireland's Evolving Constitution 1937-1997: Collected Essays, (1998), pp.135-45.

80 See the comments of Keane CJ. to that effect in "Judges as Lawmakers: The Irish Experience", address delivered to the NUI Galway Law Society, October $1^{\text {st }} 2003$. 
view of the form and function of intimate relationships. Heterosexual marriage is endorsed as the ultimate family unit and an assumption that responsibility for care of children and other dependent persons is a private and female concern runs through constitutional discourse. Arguments grounded in the equality guarantee, set out in Article 40.1, have made few inroads given the formal conception favoured by the courts. ${ }^{81}$

Another striking feature of relevant case law is the role of "social facts" in supporting dubious normative judgments about given minority groups. Whereas adjudicative facts concern the parties to a case, social or "legislative" facts relate to general policy considerations. ${ }^{82}$ Evidence of such contextual matters takes multiple forms and finds its way into adjudicative processes through a variety of routes. ${ }^{83}$ While the introduction of data produced outside law's interpretive community is regulated by rules of evidence and subject to the procedural requirements relating to a range of possible third party interventions, legal doctrine largely overlooks the manner in which judges draw on personal knowledge. Narrowly drawn rules on judicial bias comprise the main example in most jurisdictions. Boyle and MacCrimmon argue that "common sense understandings", generated by one's life experiences, permeate all levels of judicial fact-finding. ${ }^{84}$ The case law canvassed below suggests that common sense assumptions (explicit or implicit) play a heightened role in decisions involving the affective context.

Judgments have continually reiterated that the family protected by the Constitution is exclusively that based on marriage. With respect to children whose parents are not married to each other the militaristic language employed in the constitutional text resounds throughout decisions that consider even the acknowledgment of children's succession rights as an "attack" on the traditional family form. ${ }^{85}$ A series of cases concerning parentchild relations also accord considerable weight to the lesser status of extramarital affective ties rather than employing the child's best interest as the paramount consideration. ${ }^{86}$ For example, in G. $v$ An Bord Uchtála ${ }^{87}$ the

In McGee v Attorney General [1974] I.R. 284 at 319 Walsh J. stated: “. . . no interpretation of the Constitution is intended to be final for all time. It is given in the light of prevailing ideas and concepts."

81 Art.40.1 provides: "All citizens shall, as human persons, be held equal before the law. This shall not be held to mean that the State shall not in its enactments have due regard to differences of capacity, physical and moral, and of social function." The Article has never generated a finding of indirect discrimination. Its limitations are acknowledged by the Constitution Review Group, above n.78, pp.220-43.

82 K. Davis, "Judicial Notice" (1955) 55 Colum. Law Rev 945. The Supreme Court of Canada has defined legislative facts as 'those that establish the purpose and background of legislation, including its social, economic and cultural context': Danson v Ontario (A.G.) [1990] 2 S.C.R. 1086 at 1099.

83 C. Boyle and M. MacCrimmon, 'To Serve the Cause of Justice: Disciplining Fact Determination" (2001) 20 Windsor Y.B. Access Justice 55.

84 ibid.

$85 O^{\prime} B$ v $S$ [1984] IR 316. The concept of 'illegitimacy' was removed by passage of the Status of Children Act 1987, following the European Court of Human Rights decision in Johnston v Ireland (1986) 9 EHRR 203.

86 See further, The State (Nicolaou) v An Bord Uchtála [1966] IR 567; J.K. v VW. [1990] 2 IR 437; O'R. (W.) v H. (E.) [1996] 2 IR 248.

87 [1980] IR 32. 
Supreme Court established that while an unmarried mother was automatically the guardian of her child, the relationship did not amount to a "family" within the terms of the Constitution and hence their rights are neither inalienable nor imprescriptible. ${ }^{88}$ Attempts by unmarried cohabiting couples to regulate their financial position by employing cohabitation contracts have also been construed as undermining the institution of marriage. 89

Before the courts claims for recognition of relationships that fall outside the parent-child or marital family nexus are reduced to pleas for toleration. In Norris v Attorney General ${ }^{90}$ while the Supreme Court acknowledged that the criminalisation of consensual sex between men interfered with the plaintiff's right to privacy it found such interference was warranted in order to safeguard the common good. O'Higgins CJ held "on the ground of the Christian nature of our state and on the grounds that the deliberate practice of homosexuality is morally wrong, that it is damaging to health both of individuals and the public, and, finally, that it is potentially damaging to the institution of marriage, I can find no inconsistency with the Constitution in the laws which make such conduct criminal". ${ }^{91}$ The perceived threat to marriage stems from the predatory homosexual male who has the apparent capacity to lure men from "marriages which might have been successfully and happily consummated". 92

While the European Court of Human Rights adopts a more progressive stance, it also does so on terms that cling to a binary model of gender difference. ${ }^{93}$ Even celebrated decisions such as that of Karner v Austria ${ }^{94}$ fixate on the minority status of "homosexuals". Gay and lesbian people are posited as individuals with immutable characteristics that mark them out as "different" and as deserving of toleration. The background norm against which these "others" are measured - the heterosexual family unit - is not problematised. ${ }^{95}$ Indeed the assumption is that governments can legitimately prioritise conventional family forms. As I argue below, such decisions exemplify the limits of the sameness/difference approach to equality, in that it adheres to an essentialist view of human beings and does not interrogate relations of domination and oppression.

"Lesbians and gay men are granted legitimacy, not on the basis that there might be something problematic with gender roles

88 ibid., at 55.

89 Ennis v Butterly, [1996] 1 IR 426. See Law Reform Commission, above n.34, paras.3.23-3.31.

90 [1984] IR 36 (Sup. Ct.).

91 ibid., at 63. For a critical appraisal of the decision see ICCL, Equality Now for Lesbians and Gay Men (1990); Flynn, above n.79; P. Hanafin, "Rewriting desire: the construction of sexual identity in literary and legal discourse in postcolonial Ireland" (1998) 7 Social \& Legal Studies 389.

92 Above n.90, at 69.

93 See M. Grigolo, "The ECHR and Sexualities: Introducing the Universal Sexual Legal Subject" (2003) 14 EJIL 1023.

94 40016/98, [2003] ECHR 395, 24 July 2003.

95 Lise Gotell suggests that such decisions perform "a crucial role in reinforcing the naturalness of heterosexuality": "Queering Law: Not By Vriend" (2002) 17 Can. J.L.\& Soc'y 89, at 91. 
and sexual hierarchies, but on the basis that they constitute a fixed group of 'others' who need and deserve protection. Human rights frameworks thus pull in 'new' identities thereby regulating them, and containing their challenge to dominant social relations." 96

The absence of any positive affirmation of the affective ties between people is a marked feature of Irish constitutional discourse. A possible alternative locus for such claims, the constitutional guarantees of freedom of association and expression, ${ }^{97}$ recognises the importance of interpersonal connections outside the marital contract but envisages these as taking place in the public sphere, the freedom of intimate association promoted by Karst is thereby closed off to those who do not conform with traditional norms. ${ }^{98}$ Any prospect of re-imagining the family as a care-taking dyad rather than a heterosexual relation seems too remote to even contemplate. ${ }^{99}$

A common thread in judgments concerning extra-marital relationships is the omission to supply any empirical evidence demonstrating that equal treatment of the various groups concerned would undermine the institution of marriage. ${ }^{100}$ The comments of a Canadian judge in a case concerning the location of social welfare benefits are instructive "it eludes me how according same-sex couples the benefits flowing to opposite-sex couples in any way inhibits, dissuades or impedes the formation of heterosexual unions. Where is the threat?"101

The rhetorical commitment to State support for the paradigm family unit has not translated into concrete protections for the individuals who comprise it. Because the overarching concern is the promotion of an idealised family form and its protection from external forces, decisions gloss over the material conditions required to sustain care and love relations while also neglecting inequalities of power as between family members.

In 2003 the Supreme Court considered whether the constitutional protection afforded married families, specifically the ties between Irish citizen children and their third country national parents, was sufficiently weighty to overturn

96 C. F. Stychin, "Essential Rights and Contested Identities: Sexual Orientation and Equality Rights Jurisprudence in Canada" (1995) 8 Can. J.L. \& Jur. 49, at 58.

97 Art.40.6.1 $1^{\circ}$ stipulates that 'the State guarantees liberty for the exercise' of rights to freedom of expression, assembly and association 'subject to public order and morality'.

98 K. Karst, "The Freedom of Intimate Association" (1980) 89 Yale L.J. 624. See also Flynn's critique of the judgment in McGee v A.G. [1974] IR 284 which grounded the plaintiff's right to use contraception in her status as a married woman: L. Flynn, "Missing Mary McGee: The Narration of Women in Constitutional Adjudication" in G. Quinn et al eds., Justice and Legal Theory in Ireland (1995), pp.91-106.

99 M. Fineman, The Neutered Mother, The Sexual Family and Other Twentieth Century Tragedies (1995).

100 Indeed, as Justice Henchy's dissent in Norris pointed out, all of the empirical evidence presented at trial via expert testimony supported the decriminalization of consensual sex between men, above n.90.

101 Iacobucci J. in Egan v Canada, [1995] 2 S.C.R. 513, at 616. 
a deportation order directed at the adults. ${ }^{102}$ Distinguishing a precedent that dated from $1990^{103}$ the majority of the Court laid considerable emphasis on the changed wider environment and the behaviour of the applicants. Justice Hardiman for example contrasts hard-working "legitimate" migrants with the parents in question, the latter are suspect having claimed refugee status in Ireland after their claims were dismissed in the UK: the State was entitled to conclude that allowing such people to remain would undermine the "integrity of the asylum and immigration process". ${ }^{104}$ At each juncture the fact matrix drawn upon is highly selective. As Justices Fennelly and McGuinness point out in their dissenting judgments the parents' legal status and wider migration patterns are immaterial to the constitutional rights of the children involved to the company and care of their parents. Further, in considering whether parents could exercise the child's acknowledged right to choose their place of residence a dubious distinction is drawn between such capacity and decisions as to medical treatment, which the Court had previously established vest in the family, even where exercised in a manner that is not in the child's best interest. ${ }^{105}$

The finding to the effect that promotion of the asylum process overrode the constitutional protection of family life, clearly resonated with a majority of the Irish electorate, who subsequently approved a referendum designed to confine citizenship to those with Irish parentage. ${ }^{106}$ As such the amendment was a mechanism "for securing the property-like entitlement of citizenship and its accompanying benefits to 'natural-born' members - at the expense of excluding all non-right holders from claiming access to equivalent entitlements and benefits". ${ }^{107}$

The rights guaranteed by Articles 41 and 42 vest in each family member but also attach to the marital unit as a whole. ${ }^{108}$ Where the interests of individuals within the unit are perceived as undermining the "constitution and authority" of the family, however, the latter tends to prevail. Treating children's welfare as the paramount consideration may not as a result be constitutionally

102 Lobe v Minister for Justice, Equality \& Law Reform [2003] 1 IR 1; See further D. King, Immigration and Citizenship in Ireland (2004); U. Fraser, "Two-tier citizenship - the Lobe and Osayande case", Paper Presented at Women's Movement: Migrant Women Transforming Ireland, Trinity College Dublin, 20-1 March 2003.

103 Fajujonu v Minister for Justice [1990] 2 IR 151.

104 ibid., at para.366.

105 North Western Health Board v HW and NW [2001] 3 IR 622. See analysis in R. Byrne and W. Binchy, Annual Review of Irish Law 2001 (2002), at 316-338, and that of R. Arthur, "North Western Health Board v H.W. and C.W. Reformulating Irish Family Law" (2002) 2002:3 I.L.T. 39.

106 See critical commentary by J. A. Harrington, "Citizenship and the Bio-Politics of Post-Nationalist Ireland" (2005) 32 Journal of Law \& Society 424.

107 A. Shachar, "Children of a Lesser State: Sustaining Global Inequality through Citizenship Laws" Jean Monnet Working Paper 2/03 (2003), p.5. See also J. Carens, "Aliens and Citizens: The Case for Open Borders" (1997) 49 Review of Politics 251.

108 W. Duncan, "The Constitutional Protection of Parental Rights", in Government of Ireland, above n.78, at 612-626. 
sound. ${ }^{109}$ A recent statutory report notes, for example, that constitutional protection of the marital family unit in effect prevents the adoption of children whose best interests would be served by such an order. ${ }^{110}$ The constitutional guarantee of equality before the law has been deployed to remove the remaining vestiges of formal status hierarchies as between married men and women, ${ }^{111}$ but has not altered the substantive position of spouses, as becomes apparent in case law on the value of care work.

Under the social contract presented to the Irish electorate in 1937 "women were installed, as reproductive and domestic labourers, at the heart of the patriarchal and autarkic formation that was nationalist Ireland". ${ }^{112}$ Article 41.2 of the Constitution provides:

" $1{ }^{\circ}$ In particular, the State recognises that by her life within the home, woman gives to the State a support without which the common good cannot be achieved.

$2^{\circ}$ The State shall, therefore, endeavour to ensure that mothers shall not be obliged by economic necessity to engage in labour to the neglect of their duties in the home."

Irish constitutional law concerning care work falls under two heads; decisions that consider whether it is productive and so warrants redistribution of private property and judgments pertaining to State support for such work. In $L \vee L^{113}$ the Supreme Court decided that Article 41.2 could not have the effect of vesting in "wives and mothers" a share in the ownership of the family home: To acknowledge the contribution of labour undertaken in the home in this manner would go beyond the bounds of judicial interpretation, amounting to a usurpation by the courts of the functions of the legislature. A subsequent Bill that purported to confer an automatic joint tenancy on spouses was unconstitutional because its provisions did not amount to "reasonably proportionate intervention by the State with the rights of the family and constitute a failure by the State to protect the authority of the family". ${ }^{114}$ The Court does not consider the gender implications of its finding nor does it discuss the history of State-induced dependence of married women on their husbands. ${ }^{115}$

In Sinnott ${ }^{116}$ the parameters of the right to free primary education were drawn by the Supreme Court so as to exclude persons over eighteen years of age. In holding that primary education was age and not needs-related the Court effectively sanctions the continuation of an affective harm visited by State neglect of a fundamental right: over the course of some years a mother and her disabled son struggled unsuccessfully to have even the most basic of his

109 A. Shatter, Family Law, 4th ed. (1997), p.94; See also the Kilkenny Incest Investigation Report (1993).

110 Department of Health and Children, Adoption Legislation: 2003 Consultation and Proposals for Change (2005), chap.7.

111 See generally O. Doyle, Constitutional Equality Law (2004), chap.7.

112 Harrington, above n.106, p.431.

113 [1992] 2 IR 77.

114 Re Article 26 and the Matrimonial Home Bill 1993 [1994] 1 IR 305, at 326.

115 Through, e.g. the civil service marriage bar that remained in place until 1973. See further Yeates, above n.63.

116 Sinnott v Minister for Education [2001] 2 IR 545. 
educational needs met. It further rejected the plaintiff's contention that her constitutional rights had also been violated. A majority of the Court, while acknowledging that Mrs. Sinnott had assumed an onerous care burden as a result of the State's inaction, found that no such cause of action was known to the law. Yet there were, as Justice Denham found in her minority judgment, at least two possible constitutional bases for the claim: the equality guarantee and the explicit protection of the family provided for under Articles 41 and 42, which acknowledges the role of women's labour in the home and commits the State to support such work. In addition the Court might have had recourse to the reservoir of unenumerated rights that stem from Article 40.3. ${ }^{117}$ The latter have been fashioned on an ad hoc basis by the Courts since the 1960's and have given rise to new forms of claims against the State, overlapping to a degree with the Strasbourg Court's jurisprudence under Article 8 of the ECHR. ${ }^{118}$ Moreover, a strong body of precedents reiterate that a breach of constitutional rights should be remedied notwithstanding the absence of an existing cause of action. ${ }^{119}$

It is submitted that the actual rationale rests not on a legal foundation as the judiciary asserted, but on a factual finding as to the nature of care work, specifically, a common sense assumption to the effect that such work is not commodifiable but is just a natural extension of love and affection. ${ }^{120}$ As Robin West observes "an injury sustained by a disempowered group will lack a name, a history and in general a linguistic reality". ${ }^{121}$

Demarcation of care work as a female "duty" also surfaced in Lowth $v$ Minister for Social Welfare. ${ }^{122} \mathrm{Mr}$. Lowth sought equal treatment to a deserted wife in the form of State benefits. His claim failed on the basis that differences in treatment between the two groups concerned were justified because the legislation was pursuing a valid objective, that is, supporting the social function ascribed to women under the Constitution. It was of course open to the Court to hold that the purpose of the legislation was to provide financial support to persons who were at risk of poverty, rather than classifying the legislature's objective as one of supporting gendered social roles.

Judgments such as this and Norris ${ }^{123}$, conceptualise the ill to be remedied by the equality guarantee as one of arbitrary differentiation based on inherent human characteristics. Article 40.1 is violated only if an impugned classification does not treat all those who are similarly situated with respect to the purpose of a law in the same manner. Three facets of this test are

117 The foundational case is Ryan v Attorney General [1965] IR 294.

118 Many of the un-enumerated rights "discovered" to date implicate close personal relationships: the rights to marital privacy, individual privacy, to communicate, to bodily integrity and to know the identity of one's birth mother. See further J. Casey, Constitutional Law in Ireland (2000), p.395.

119 See judgment of Denham J., above n.116, at paras.159-66.

120 On the conflation of love and care labour by the U.S. courts see K. Silbaugh, "Turning Labor Into Love: Housework and the Law" (1996) 91 Nw. U. L. R.ev 1.

121 R. West, "The Difference in Women's Hedonic Lives: A Phenomenological Critique of Feminist Legal Theory" (1987) 3 Wisconsin Women's L.J. 81, at 85.

122 [1999] 1 ILRM 5. See commentary by G. Hogan, "The Supreme Court and the Equality Clause" (1998) 4:3 Bar Rev 116.

123 Above n.90. 
especially problematic. Its malleability means that the "reasonableness" of a distinction depends entirely on how one construes a measure's overarching function, as the Lowth decision amply demonstrates. Further, since discrimination is posited as irrational differentiation rather than subordination, the similarly situated test does not distinguish between using a classification to shore up privilege or challenge it. ${ }^{124}$ A final flaw explains in part the judiciary's failure to tackle economic inequality. Absent express protection, socio-economic rights can achieve constitutional recognition in two principal ways; through an expansive reading of textual civil and political rights or via equality guarantees. ${ }^{125}$ Neither of these paths has been followed. The latter is closed off because substantive inequalities do not give rise to actionable Article 40.1 claims, unless a formal distinction is drawn between groups.

In any event, the separation of powers doctrine presents a seemingly insurmountable obstacle to the imposition of the positive duties courts associate with socio-economic rights on the other branches of government. ${ }^{126}$ The Supreme Court overturned a High Court order directing the State to adhere to its own time-scales for the building of special-care and highsupport units for children at risk in T.D. $v$ Minister for Education and Others. ${ }^{127}$ The case supplies a stark example of self-imposed judicial restraint especially given that the right in issue was an enumerated one - the right to primary education. Many of judges accepted that in principle the plaintiffs' constitutional rights had been violated - in other words the Court appeared to accept that the right to education imposed positive duties on the State - but nonetheless refused to grant the remedy sought. Tushnet concludes that the decision reduces the right to primary education to a low status "declaratory right", which is no different in essence a non-justiciable right: "A purported right without an accompanying judicially enforceable obligation, is almost literally, toothless." 128

In issuing something akin to a declaration of incompatibility the Irish courts seek to preserve a bright line between the legal domain and "political" distributive justice matters. ${ }^{129}$ However, without an inter-branch dialogue mechanism for dealing with such putative rights violations ${ }^{130}$, a state of

124 V. Vojdik, "Gender Outlaws: Challenging Masculinity in Traditionally Male Institutions" (2002) 19 Berkeley Women's L. J. 68.

125 See further Fabre, above n.2, and P. Hunt, Reclaiming Social Rights (1996).

126 The bedrock decision is that of Costello J. in O'Reilly v Limerick Corporation [1989] ILRM 181. For a critical evaluation of the reasoning employed in such cases see G. Whyte, Social Inclusion and the Legal System: Public Interest Law in Ireland (2002); T. Murphy, "Economic Inequality and the Constitution", in Murphy and Twomey, above n.79, pp.163-181.

127 [2001] 4 IR 259. See further C. O'Mahony, "Education, Remedies and the Separation of Powers" (2002) 24 DULJ 57.

128 M. Tushnet, "Social Welfare Rights and the Forms of Judicial Review" (2004) 82 Texas L. Rev 1895, at 1901.

129 A line which Whyte demonstrates is not that clear-cut, above n.126, chap.1.

130 A limited exception to the general position arises under the terms of the European Convention on Human Rights Act 2003. Under s.5, a court can make a 'declaration of incompatibility' with the Convention's provisions, in respect of a law or public policy. The declaration is placed before the houses of the Oireachtas 
inertia or stagnation in key areas of social policy results ${ }^{131}$, as the fate of children in need of State care attests. ${ }^{132}$ As I discuss below once "democracy" is no longer viewed as a narrow institutional role question, but as a normative concern, this rigid construction of the separation of powers doctrine demands revision. Intervention on behalf of groups who have no access to effective political representation, such as children, should raise different considerations from those applicable to members of relatively powerful groups. ${ }^{133}$ Further, while economic inequalities cannot and should not be altered by judicial fiat, institutional competency difficulties can arguably be met at the level of remedies.

\section{Towards a care-full conception of citizenship}

Societies cannot make anyone love anyone else, and to this extent the right to have loving and caring relations is not directly enforceable. ${ }^{134}$ But proponents of equality of condition contend that societies must work to establish the conditions in which these relationships can thrive. A key element in this task is to make sure that the work involved in providing love and care is properly recognized, supported and shared. The quality of people's interpersonal relations is also affected by the other dimensions of equality: equal respect, equal access to resources and equal power. Equality in these other dimensions is important in protecting people involved in relations of love and care from domination and exploitation. ${ }^{135}$ While dependence is endemic to human relations regardless of gender, ${ }^{136}$ Fineman points out that the "derivative dependency" experienced by caretakers is not a universal experience. ${ }^{137}$ Likewise disability theorists have critiqued the manner in which people are rendered dependent and hence vulnerable to exploitation by disabling cultures and environments. ${ }^{138}$

"By not noticing how pervasive and central care is to human life, those who are in positions of power and privilege can continue to ignore and to degrade the activities of care and those who give care. To call attention to care is to raise questions about the adequacy of care in our society. Such an

(Irish parliament) within 21 days of the court hearing; there is no further guidance as to what should occur at that juncture.

131 J. Lobel, "The Political Tilt of the Separation of Powers", in Kairys, above n.13, pp.591-616.

132 Irish Times, 29 December 2003.

133 On the need for a context-sensitive approach to the separation of powers doctrine see M. Minow, Making all the Difference: Inclusion, Exclusion, and American Law (1990), pp.361-362.

134 For example, parents are legally required to care for their children, but they cannot be forced to care about them.

135 See further Bubeck and Kittay, above n.7.

136 N. Fraser and L. Gordon, "A Genealogy of 'Dependency"' in Fraser, above n.4, at pp.121-149.

137 M. Fineman, The Autonomy Myth: A Theory of Dependency (2003).

138 J. Morris, Independent Lives?: Community Care and Disabled People (1993) M. Oliver, The Politics of Disablement (1990); T. Shakespeare, "The Social Relations of Care", in G. Lewis, S. Gewirtz and J. Clarke eds., Rethinking Social Policy (2000), at pp.52-65. 


$$
\begin{aligned}
& \text { inquiry will lead to a profound rethinking of moral and } \\
& \text { political life." } 139
\end{aligned}
$$

Care relations, including the emotional, material, social and political costs involved in sustaining them, are profoundly important matters that demand a radically improved public response. The remainder of this paper isolates some core features of a relational approach to rights. Probing its methodological implications, I argue that the envisaged contextual, care-full analysis of rights can only emerge through transformation of the social relations of knowledge production within the legal field.

Given its location at the intersection of State and civil society, the legal system's regulation of the affective domain has generated a considerable body of literature. Relational scholars, by foregrounding the interdependence of all human beings from the inner circles of care, what we might term "love relations", radiating outwards to various public spheres ${ }^{140}$, challenge the implicit individualism of the legal subject. Naffine for example shows how the ostensibly autonomous, contracting individual is gendered: Men's dependencies and needs are met within the unacknowledged private sphere, thus woman sustains the "impossible paradox of the man of law". ${ }^{141}$ By equating liberty with non-interference, the right to privacy including the decisional autonomy of the family as advanced in the judgments discussed above, cordons off aspects of this important sphere of life from public scrutiny. Separation is valorized above connection leading to the devaluation and invisibility of care work in judgments pertaining to both interpersonal relationships and the State-individual axis considered in socio-economic rights jurisprudence. ${ }^{142}$

In essence feminist writers in particular seek to reconstitute the provision of love and care as public goods. ${ }^{143} \mathrm{We}$ require an integrated conception of the work performed across all spheres, in recognition of the fact that unwaged labour currently subsidizes employment in the market and should no longer assume that nurturing work is "given as a gift to either the dependant or the society that benefits". ${ }^{144}$ Rights retain their appeal as a means of ensuring that the self is not effaced by adherence to communitarian norms, which can lead to erasure of the female as subject within the family. ${ }^{145}$

139 J. Tronto, Moral Boundaries: A Political Argument for an Ethic of Care (1993), p.111.

140 See generally Nussbaum and Glover, above n.7.

141 N. Naffine, Law and the Sexes (1990); See also F. Olsen, "The Family and the Market: A Study of Ideology and Legal Reform" (1983) 96 Harv L. Rev 1497;

142 See for example, Naffine above n.141; West above n.121; R. West, "Jurisprudence and Gender" (1988) 55 U. Chi. L. Rev 1; R. West, "Reconstructing Liberty" (1992) 59 Tenn. L. Rev 441; White and Tronto, above n.77.

143 See further Fineman, above n.137; R. Lister, Citizenship: Feminist Perspectives (1997).

144 M. Fineman, above n.99, p.9.

145 See generally M. Minow and M. L. Shanley, "Relational Rights and Responsibilities: Revisioning the Family in Liberal Political Theory and Law" (1996) 11 Hypatia 4. One reply to the charge that rights discourse generates conflict between individuals and so threatens co-operative social relations is that rights themselves do not fuel adversarial positions but are in place in the event 
Taking the interdependence of self and others seriously, summons a care-full vision of citizenship that should inform constitutional doctrine concerning rights in general, not just those concerning intimate associations. ${ }^{146}$ As Nedelsky puts it "our 'private rights' always have social consequences". ${ }^{147}$ Once we accept that rights are relational we can no longer for example, regard the protection of private property rights as utterly divorced from the legal response to the claims of those living in poverty. Jurisprudence on socio-economic rights feeds into the construction of certain groups as needy objects of policy, whose claims should be advanced through the political process rather than before the courts. ${ }^{148}$ Redistributive measures are often construed as unfair attempts at transferring the costs of social "problems" onto an innocent group. ${ }^{149}$ That reasoning underpinned the decision in $R e$ Article 26 and the Employment Equality Bill 1996, ${ }^{150}$ where the Irish Supreme Court found that a reasonable accommodation provision constituted an unjust attack on the property rights of employers, specifically the right to carry on a business and earn a livelihood. Several ideological and practical problems flow from the designation of remedial measures as exceptional. The implication is that the difficulties encountered by various groups in participating in social life are traceable to their own problematic attributes rather than to unequal social structures bolstered by the operation of capitalist economies. The alternative to sharing or transferring costs is of course to leave things exactly as they are, that is, the costs of structural inequalities, both fiscal and personal continue to be borne solely by members of disadvantaged groups, a fact which was acknowledged by the Canadian Supreme Court in Brooks v Canada Safeway. ${ }^{151}$

Moreover, such judgments obscure the extent to which the fulfilment of negative duties is resource intensive:

"Even conventional individual rights, like the right to free speech and private property, require governmental action. Private property cannot exist without a governmental apparatus, ready and able to secure people's holdings as such. So-called negative rights are emphatically positive rights. In fact all rights, even the most conventional, have costs. Rights of property and contract, as well as rights of free speech and religious liberty, need significant taxpayer support."152

that relations break down: J. Waldron, "When Justice Replaces Affection: The Need for Rights" in Liberal Rights: Collected Papers 1981-1991 (1993).

146 See further Nedelsky, above n.26.

147 Above n.26, at 17.

148 See further Tronto and White, above n.77.

149 C. Harris, "Whiteness As Property" (1993) 106 Harv L. Rev 1710.

150 [1997] 2 IR 321. According to the Ninth Progress Report of the All-Party Oireachtas Committee on the Constitution (2004), at 28:

"It must be acknowledged ... that the reasoning in this case stands out as the most pro-property rights decision of recent years. It is, perhaps, one of the few instances where a legislative measure was found to be unconstitutional on this ground where the arbitrary or unfair character of the impugned legislation was not self-evident."

151 [1989] 1 S.C.R. 1219

152 C. Sunstein, Designing Democracy: What Constitutions Do (2001), at 222-223. 
Substantive equality guarantees are potentially a fruitful means of unpacking the relational nature of all constitutional rights. As mentioned above, formal equality analysis fixates on the individual claimant's supposed traits and neglects to highlight the oppressive practices of the powerful. The "reasonable classification" approach also clings to an understanding of difference as inherent and binary rather than viewing it as multiple and relational. ${ }^{153}$ Critical theorists have forcefully argued that inequalities are not attributable to "differences" as such, but to the difference that difference makes. In other words differentiation is not the harm that ought to be addressed; subordination is. ${ }^{154}$ Although there is some evidence of retrenchment the Canadian and South African Courts have applied relational, as opposed to comparative, equality analysis on occasion. Judgments of Justice Sachs have explored the social construction of sexual identities as well as their dynamic relation to dominant norms. ${ }^{155}$ In advocating a revised stance towards Section 15 of the Canadian Charter, Justice L'Heureux Dubé comments:

"We will never address the problem of discrimination completely, or ferret it out in all its forms, if we continue to focus on abstract categories and generalizations rather than on specific effects. By looking at the grounds for the distinction instead of at the impact of the distinction on particular groups, we risk undertaking an analysis that is distanced and desensitized from real people's real experiences."156

The central idea here is that substantive inequalities are best tackled by focusing on the impugned act or omission, rather than on the defining the group to which a claimant belongs. ${ }^{157}$ Such analysis prompts us to appreciate that particular rights are not properly understood until viewed as part of a larger context. In turn, the knowledge of context that we rely on should be generated by the groups at the receiving end of unequal treatment.

"Human rights structure relationships not only by regulating patterns of behaviour but also by putting in place a method of claiming rights and creating a framework for a remedial dialogue between those who are disadvantaged or left out and those who are in positions of power and authority."158

153 K. Crenshaw, "Demarginalizing the Intersection of Race and Sex: A Black Feminist Critique of Anti-Discrimination Doctrine, Feminist Theory and Antiracist Politics' (1989) 139 U. Chic. Legal Forum 157; A. Harris, "Race and Essentialism in Feminist Legal Theory" (1990) 42 Stan. L. Rev 581.

154 R. Colker, "Anti-Subordination Above All: Sex, Race, and Equal Protection" (1986) 61 N. Y. U. L. Rev 1003; MacKinnon, above n.13.

155 See P. De Vos, "Same-Sex Sexual Desire and the Re-Imagining of the South African Family" (2004) 20 SAJHR 179.

156 Egan v Canada [1995] 2 SCR 513, at 551-552.

157 Minow, above n.133, p.101.

$158 \mathrm{~J}$. Birenbaum and B. Porter, Screening rights: The denial of the right to adjudication under the Canadian Human Rights Act and how to remedy it (1999). Available from http://www.law.utoronto.ca/. 
In other words, the manner in which rights are institutionalised is best understood as a "dialogue of democratic accountability". ${ }^{159}$ Power inequalities mean, however, that the perspectives of some groups continually go unheard. In the following section I argue that rights interpretation needs to be informed by experiential knowledge of inequalities.

\section{Democratising legal-decision-making}

Judges frequently present what is a select viewpoint as one that is more comprehensive and epistemologically powerful than others. ${ }^{160}$ As Martha Minow comments: "Court judgments endow some perspectives, rather than others, with power. Judicial power is least accountable when judges leave unstated - and treat as a given - the perspective they select."161 Within traditional adjudicative processes reflexivity is not a requirement of the judicial task. The net effect of interpreting the world from the perspective of the "expert" is that the viewpoint of the outsider is privileged over that of the insider who has experienced the inequality. Privileging of the "expert" therefore produces perspectives on inequality and injustice that are not only politically and emotionally detached from the experiences that generated their articulation in the first place but dominate those experiences in legal discourse. Moreover, law's claim to enunciate "truths" in the form of detached and objective judgments mean that the partial, socially and historically contingent aspects of legal decision-making are continually masked. Adjudication is presented as a neutral exercise in rule application and law's coherence is supposedly assured through following principles elaborated in prior cases. ${ }^{162}$

Experiential knowledge - "knowing a person or thing through sustained acquaintance" 163 - provides a perspective on the world that does not have an explicit home in legal methodology. Yet people's experiences inevitably colour their affective responses to given situations. In turn affect is a "crucial component of judgment and reason". ${ }^{164}$ Following Hannah Arendt, Nedelsky argues that, while there is no such thing as objective judgment, it is nevertheless possible, indeed important, to strive for good judgment. ${ }^{165}$ To form a "good" judgment we must transcend our private idiosyncrasies, and we do this by testing our perspective against those of others. The more standpoints we consider, the better our own standpoint and hence our judgment will be. By virtue of their personal experience, those who carry the burden of inequality often have a better vantage point for understanding the

159 Nedelsky, above n.26, argues that a relational approach to rights posits constitutionalism as a 'dialogue of democratic accountability'. See also Minow and Shanley, above n.145.

160 Bourdieu, above n.13; D. Kennedy, "Legal Education as a Training for Hierarchy" in Kairys, above n.13, pp.54-75; MacKinnon, above n.13; M. Minow, 'Feminist Reason: Getting It and Losing It' (1998) 38 J. Leg. Ed. 47.

161 M. Minow, "Foreword: Justice Engendered" (1987) 101 Harv L. Rev 10, at 94.

162 Bourdieu above n.13.

163 J. Heron, "Philosophical Basis for a New Paradigm" in P. Reason and J. Rowan eds., Human Inquiry: A Sourcebook of New Paradigm Research (1981), at p.27.

164 J. Nedelsky, "Embodied Diversity and the Challenges to Law" (1997) 42 McGill L. J. 91, at 106; See also discussion by Nussbaum, above n.7.

165 J. Nedelsky, "Communities of Judgment and Human Rights" (2000) 1 Theoretical Inquiries in Law 1. 
social world that creates inequality than those who enjoy its advantages. They can have a much deeper understanding of how particular laws, policies and procedures operate to promote inequalities than those who are advantaged by them. ${ }^{166}$

Third party interventions in public law proceedings are a valuable mechanism for giving a voice to people with day-to-day experiential knowledge of injustice. ${ }^{167}$ Significantly, they differ qualitatively from the technical expert evidence usually drawn upon by courts and enable the presentation of issues in a form that emphasises their relational and affective dimensions. ${ }^{168}$ Further, unlike expert evidence or individual client narratives, briefs can have an application wider than the facts of the case at hand. Social structures that contribute to the subordination of minority groups become most visible in the aggregate accounts of inequality furnished by representative organisations.

Under current conditions, written judicial opinions explain the court's findings solely as outcomes of a reasoned elaboration of legal materials. ${ }^{169}$ As a step towards realising greater accountability, judges should be obliged to address the arguments put forward in these dossiers and explain how their decisions affect relationships between groups in addition to individual litigants. ${ }^{170}$ In essence, this would require judgments to include an equality impact assessment and not just a decision on the particular case at hand.

It is submitted that critiques of legal method have to date paid insufficient attention to the question of legal remedies. In other words, the range of possible orders that flow from a decision inevitably shape the lead-in adjudicative processes, including the place accorded experiential knowledge of inequality. Irish constitutional litigation generally constructs what are essentially questions about relationships between various groups as narrow matters about the particular claimant's assertion of rights against another individual or entity. Inter-group relations, in typical adversarial mode, are analysed as inter-personal contests, in which a winner and loser must be identified. ${ }^{171}$ In certain jurisdictions public interest law facilitates judicial review of institutional practices that affect given social groups rather than

166 M. J. Matsuda, "Looking to the Bottom: Critical Legal Studies and Reparations" (1987) 22 Harv C. R.-C.L. L. Rev 323; R. Connell, Schools and Social Justice (1993), at pp.39-41; b. hooks, Teaching the Transgress: Education as the Practice of Freedom (1994).

167 P. Bryden, "Public Interest Intervention in the Courts" (1987) 66 Can. Bar Rev 490; S. Fredman, "Judging Democracy: The Role of the Judiciary under the Human Rights Act 1998' (2000) 53 CLP 99.

168 See, e.g. the briefs submitted by the Canadian women's rights organisation, LEAF, available at http:www.leaf.ca/.

169 See R. Cotterrell, Law's Community: Legal Theory in Sociological Perspective (1995), at pp.65-6; K. Klare, "Legal Culture and Transformative Constitutionalism" (1998) 14 SAJHR 146.

170 Kearney and Merrill note that US courts do not even refer to amicus briefs in a large proportion of cases: "The Influence of Amicus Curiae Briefs on the Supreme Court" (2000) 148 U.Pa.L.Rev 743.

171 C. Menkel-Meadow, "The Trouble with the Adversary System in a Postmodern, Multicultural World" (1996) 38 Wm.\& Mary L.Rev 5. 
focussing solely on the rights of individuals. ${ }^{172}$ However, many of these models simply augment the power of courts, in that they engage in ongoing supervision of how other social institutions operate, without securing an effective voice for subordinate people. The work of Dorf and Sabel on courts as sites of "democratic experimentalism", supplies a useful starting point for re-thinking public law remedies in a manner that addresses concerns as to appropriate institutional roles. ${ }^{173}$

Creative use of public law remedies could strengthen democratic legitimacy by avoiding either/or dispositions of cases. ${ }^{174}$ Courts could, for example, issue judicial decrees requiring a structured participatory process for resolving a particular problem, with a clear role for the groups it affects and an appropriate statutory human rights or equality agency. ${ }^{175}$ In other words, the judicial role need not necessarily be exclusively reactive. Dorf and Sabel suggest that courts are well placed to proactively direct collective problemsolving capacities: by setting out general performance standards and duties of coordination and cooperation that must be met by the relevant public body, while leaving the precise manner of this up to the institution concerned and affected parties. ${ }^{176}$ The "best" decision may turn out to be one that does not entail the traditional first instance finding of unconstitutionally but one that generates more "experimentalist" remedies aimed at reforming practices of legislatures and bureaucracies. Any such role would involve abandoning the notion that the application of legal methods to social problems necessarily arrives at the "correct" result. As Klare remarks, lawyers "can best address problems concerning the democratic legitimacy of judicial power by honesty about and critical understanding of the plasticity of legal interpretation and of how interpretive practices are a medium for articulating social visions". ${ }^{177}$

However, the inclusion of subaltern perspectives within adjudicative processes and the placement of laws within their wider social context cannot of itself assure egalitarian outcomes. ${ }^{178}$ The Supreme Court judgments in Lobe $^{179}$ and Norris ${ }^{180}$ demonstrate how contextual factors can be used to

172 See for example, A. Chayes, "The Role of the Judge in Public Law Litigation" (1976) 89 Harv Law Rev 1281.

173 M. Dorf \& C. Sabel, "A Constitution of Democratic Experimentalism" (1998) 98 Colum. Law Rev 267; M. Dorf, "Legal Indeterminacy and Institutional Design" (2003) 78 N.Y.U.L.Rev 875.

174 C. Scott and P. Macklem, "Constitutional Ropes of Sand or Justiciable Guarantees? Social Rights in a New South African Constitution” (1992) 141 U.Pa.L.Rev 1.

175 Under s.8(h) of the Human Rights Commission Act 2000, the IHRC is already empowered to apply to act as amicus in cases concerned with the human rights of any person. Liberty to intervene is at the discretion of the courts and the power has been exercised twice to date. See further the Commission's website: http://www.ihrc.ie/. The Equality Authority is also due to act as amicus for the first time in a judicial review of the Housing (Miscellaneous Provisions) Act 2002: http://www.equality.ie/.

176 Above n.173.

177 Above n.169, at p.187.

178 See Lacey, above n.13, chap.1.

179 Above n.102.

180 Above n.90. 
rationalise dubious treatment of minority groups. For example, when faced with a choice between the social and medical model of disability, judges may well still opt for the latter. ${ }^{181}$ An approach grounded in a relational understanding of rights mandates that adjudicators "look to the bottom", ${ }^{182}$ echoing Ann Scales' call for the rejection of epistemological privilege:

"When the law must chose between realities, the principle of equality requires that we look to see whose dignity is most at stake, whose point of view has historically been silenced and is in danger of being silenced again, and that, in the ordinary case, we chose that point of view as our interpretation." 183

Unless constitutions specifically endorse transformative objectives, through for example interpretive clauses and substantive equality guarantees, the legal system may well end up preserving the status quo and containing change within confines set by an un-elected arm of the state. It remains to be seen whether such concerns will be taken on board by those currently charged with reviewing the operation of the Irish Constitution. ${ }^{184}$

\section{Conclusion}

"Equality" is open to many interpretations, as are such related concepts as rights and the public/private distinction. Critical legal scholars and social movements have shown that rights can be understood in wider and more progressive ways than those found in conventional legal analysis. But as Williams argues, these understandings will only emerge if courts and the legal profession are prevented from monopolizing the interpretive process. ${ }^{185}$ What is at issue here is the case for an extended epistemology within the legal system so that a relational understanding of rights finds a home within adjudication. As will be gleaned from the case law canvassed above legal forms often frame social relations in narrow and confining ways and may inculcate particular understandings of problems or force claimants to adopt problematic identities. ${ }^{186}$ However within any hegemonic order there are

181 See Re Article 26 and the Employment Equality Bill 1996, above n.150 .

182 Matsuda, above n.26.

183 A. Scales, "Feminist Legal Method: Not So Scary" (1992) 2 UCLA Women's L.J. 1, p.27.

184 Currently we are more than mid-way through the second comprehensive examination of the Irish Constitution and its operation. The first phase involved the report of the Expert Group on the Constitution delivered in 1996, above n.78. For appraisals of the report see, A. Butler and R. O'Connell. "A Critical Analysis of Ireland's Constitutional Review Group Report” (1998) 33 Irish Jurist 237; S. Mullally, "Equality Guarantees in Irish Constitutional Law: The Myth of Constitutionalism and the Neutral State" in Murphy and Twomey, above n.79, pp.147-161; and Murphy, above n.126. An Oireachtas committee is now considering that report; the ten reviews have not highlighted the absence of any interpretive clauses in the text of the Constitution, which direct the judiciary to advance egalitarian values: http://www.constitution.ie/.

185 Williams, above n.20, at 433 .

186 For a discussion of legal forms see B. Fine, Democracy and the Rule of Law (1984); R. Fletcher, "Legal Forms and Reproductive Norms" (2003) 12 Social \& Legal Studies 217; S. Gavigan, "Legal Forms, Family Forms, Gendered Norms: What is a Spouse?" (1999) 14 Can. J. L. \& Soc'y 127. 
cracks and contradictions that can be exploited. ${ }^{187}$ While courts should not supplant democratic decision-making processes, they could play an important role in advancing political debate, prompting rather than inhibiting the emergence of a care-full conception of citizenship.

187 D. Sugarman, "Law, Economy and the State in England, 1750-1914: Some Major Issues" in Sugarman ed., Legality, Ideology and the State (1983), pp.213-266. 